\title{
Larval morphology and biology of four Netocia and Potosia species (Coleoptera: Scarabaeoidea: Cetoniidae: Cetoniinae)
}

\author{
Estefanía MiCÓ* and Eduardo GALANTE \\ Centro Iberoamericano de la Biodiversidad (CIBIO), Universidad de Alicante, 03080 - Alicante, Spain
}

Key words. Scarabaeoidea, Cetoniidae, Cetoniinae, Potosia, Netocia, larval morphology, taxonomy, key, larval biology

\begin{abstract}
The larvae of Netocia morio (Fabricius, 1781), Netocia oblonga (Gory \& Percheron, 1833), Potosia opaca (Fabricius, 1787) and Potosia cuprea brancoi Baraud 1992 are described. Comparison of the morphology of both genera revealed important differences in raster structure, mandibles and frontal setae. The systematic position of both genera based on larval characteristics is discussed. Some aspects of larval biology are discussed.
\end{abstract}

\section{INTRODUCTION}

Netocia Costa, 1852 and Potosia Mulsant \& Rey, 1871 are among the most diverse cetoniine genera of the Palaearctic region, comprising a total of 29 and 26 species respectively (Krajčík, 1998). Both genera have been considered as subgenera of Protaetia Burmeister, 1842 by many authors (Krikken, 1984; Miksić, 1987). Before the Medvedev (1964) classification, more than 250 species were traditionally included in Protaetia. In his review of Russian cetonids, Medvedev (1964) placed oriental species in Protaetia, and most of the European species in Potosia. This classification was followed by many authors who considered Cetonischema Reitter, 1898, Liocola Thomson, 1859, Eupotosia Miksić, 1954, Foveopotosia Miksić, 1959 and Netocia as subgenera of Potosia (Janssens, 1960; Báguena, 1967; Baraud, 1977). These subgenera were elevated to genera (Baraud, 1992) except for Netocia and Potosia, which remained together until Tauzin (1993). Systematic studies of the group have focused on adult morphology and there has been no consideration of larvae. However, studies of larvae suggested that larval morphology could be very useful in the systematic analysis of Scarabaeoidea (Ritcher, 1966; Edmonds \& Halffter, 1978; Verdú et al., 1998).

In spite of their wide distribution, little is known about the life history and larval morphology of Cetoniinae. The most important contributions to the knowledge of Palaearctic species were provided by Golovjanko (1936), Korschefsky (1940), Van Emden (1941) and Medvedev (1952). Several years later, Klausnitzer \& Krell (1997) improved the third larval instar key of Medvedev (1952) by adding the species described by other authors. However, none of these contributions represented a complete description and no more new descriptions of Palaearctic larvae were published.

In this study, we describe the third larval instar of Netocia morio, Netocia oblonga, Potosia opaca and Potosia cuprea brancoi. Both Netocia species and
Potosia opaca occur in the occidental Mediterranean basin. Potosia cuprea (Fabricius, 1775) is widely distributed in Europe and it is represented by $P$. cuprea branco $i$ in the Iberian Peninsula. The larva of $P$. cuprea was described in part by Korschefsky (1940), Van Emden (1941) and Medvedev (1952). However, these descriptions are of $P$. cuprea metallica (Herbst, 1782) (Medvedev, 1952; Klausnitzer \& Krell, 1997). The aim of this study was (1) to test the validity of genus status of both genera based on larval morphology, (2) to provide a key of the third instar larvae of the species, and (3) an account of the larval biology of the species.

\section{MATERIAL AND METHODS}

A total of 6-10 adult specimens (males and females) of each species were kept in plastic breeding cages $(15 \mathrm{~cm}$ high, $27 \mathrm{~cm}$ wide) with flowers (Asteraceae: Carduinae) and soil with vegetable matter. The lid was an opening $(12 \mathrm{~cm}$ in diameter) covered with a gauze screen. These breeding cages were maintained in an environmental chamber at $25^{\circ} \mathrm{C}: 20^{\circ} \mathrm{C}$ (L : D), $80 \pm 5 \%$ $\mathrm{RH}$, and a photoperiod of $15 \mathrm{~L}: 9 \mathrm{D}$. Larvae were feed on ripe fruit (N. morio, P. opaca, P. cuprea brancoi), milled rabbit dung and decaying vegetable mater ( $N$. oblonga). The breeding cages were examined weekly and the results recorded. Larvae collected in the field were reared to the adult stage in the above laboratory conditions.

The different larval instars of each species were fixed in KAAD solution (Carne, 1951) for $24 \mathrm{~h}$ and preserved in 70\% ethanol. Specimens are deposited in the Entomological Collection of the University of Alicante, Spain. In the description of larvae the anatomical designations of Ritcher (1966) and Micó et al. (2001) were used.

\section{RESULTS}

\section{Netocia morio (Fabricius, 1781) third instar larva}

(Figs 1-13)

The larval description is based on 20 third instar larvae and 5 second instar larvae reared from eggs laid by adults

\footnotetext{
* Corresponding author. Centro Iberoamericano de la Biodiversidad (CIBIO), Universidad de Alicante, San Vicente del Raspeig, E-03080, Alicante,Spain. E-mail: e.mico@ua.es
} 

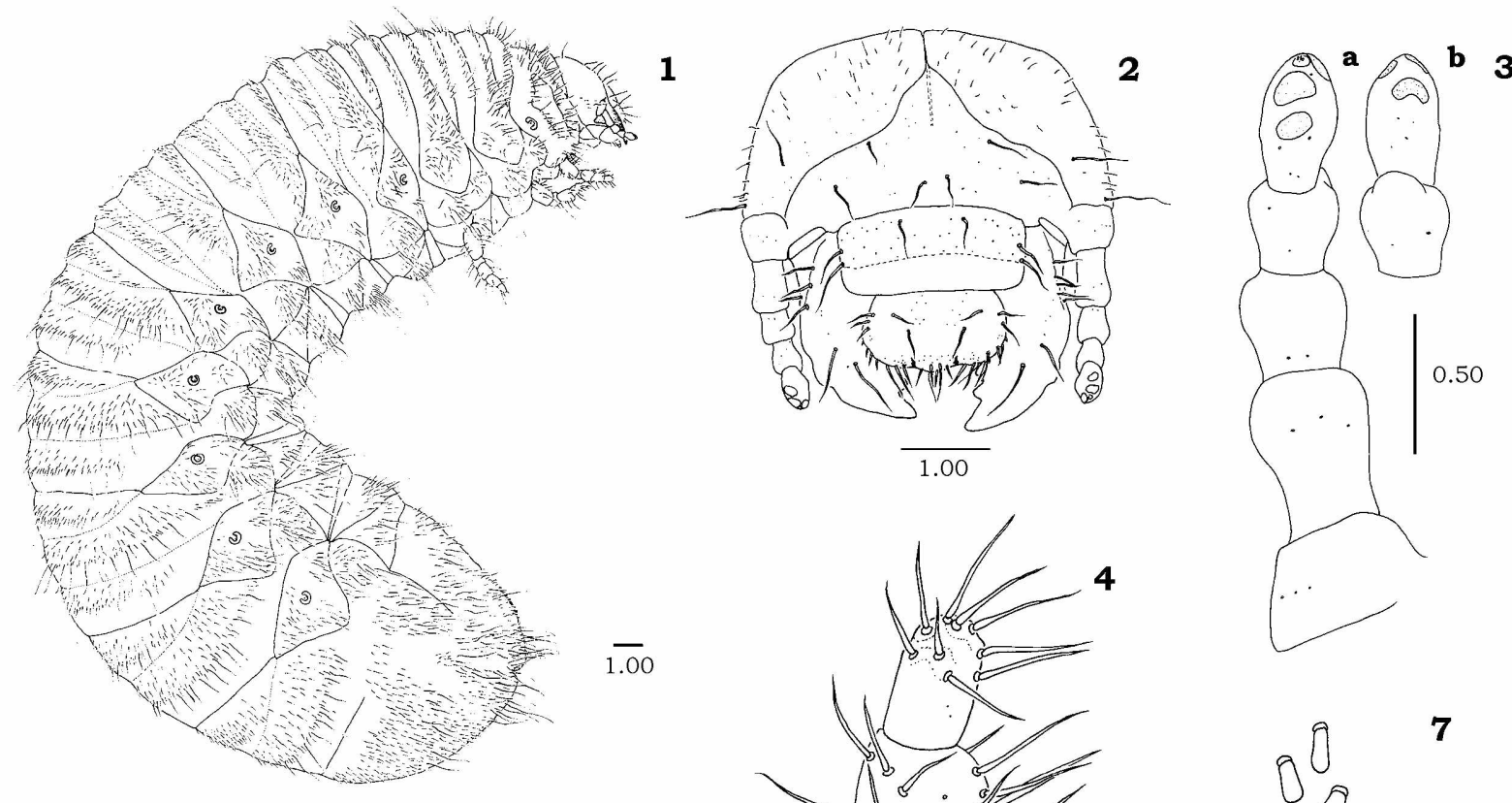

\section{3}
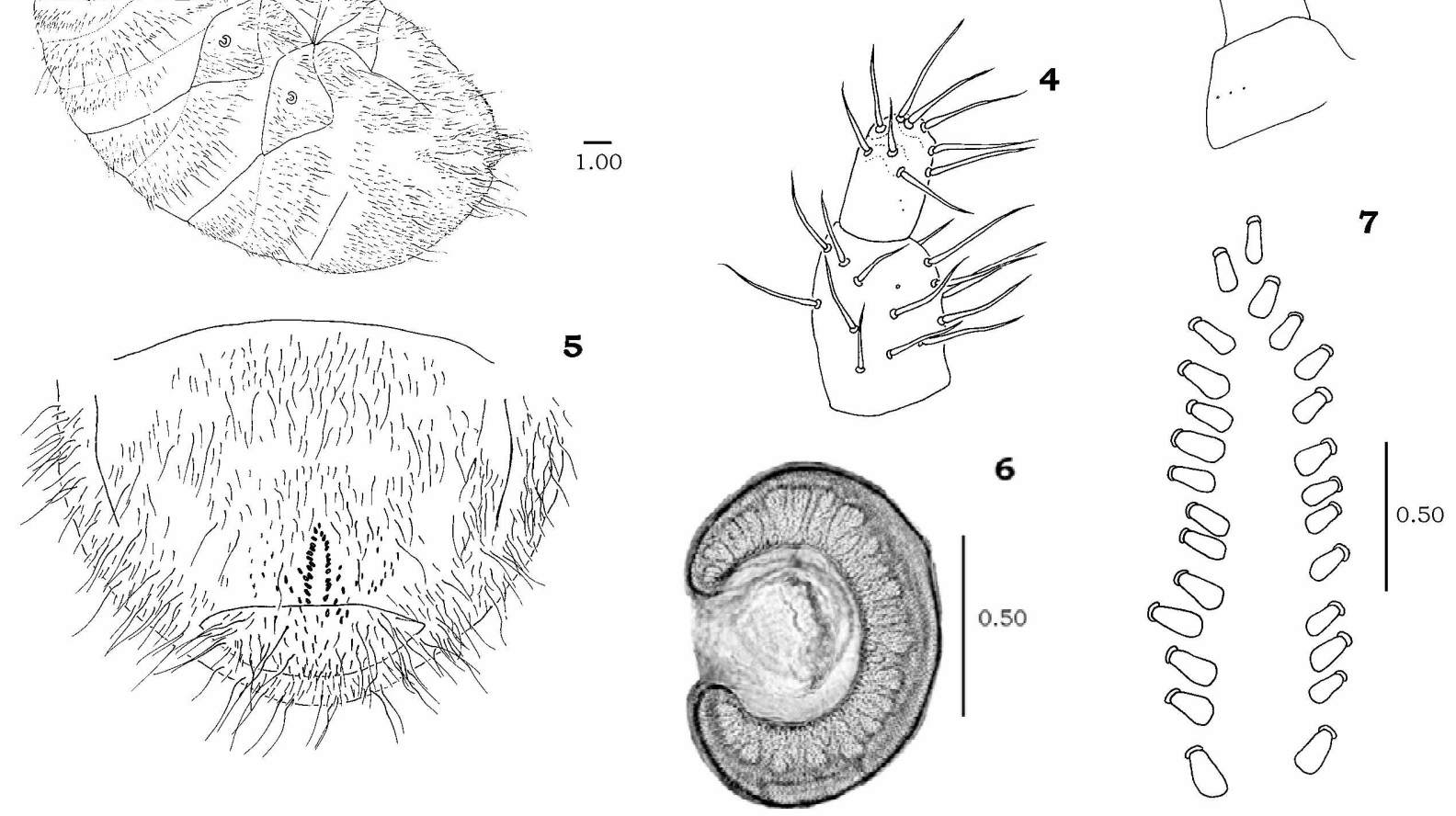

Figs 1-7. Netocia morio third-instar larva. 1- habitus; 2 - frontal view of head; 3 - dorsal view (a) of antenna and ventral view (b) of apical antennal segment showing sensory spots; 4 - detail of tarsungulus and tibiae of prothoracic leg; 5 - venter of last abdominal segment; 6 - prothoracic spiracle; 7 - detail of palidium.

collected at "La Granadella", Alicante (Spain), V-1996, Micó \& Verdú leg.

Head. Maximum width of head capsule $4.5 \mathrm{~mm}$. Cranium (Fig. 2). Colour light yellow. Dorsoepicranium with 20-30 short and unordered setae on each side. Frons sparsely punctate, with 1 anterior seta, 1 posterior seta, 1 external seta and 1 anterior angle seta on each side. Labrum (Fig. 2). Trilobed, narrower than clypeus; clithra present. Epipharynx (Fig. 8). Plegmatium absent. Corypha with 4 long setae flanked by $2-3$ sensilla on each side. Acanthoparia with 7-12 short, stout setae decreasing in size posteriorly. Chaetoparia welldeveloped, covered with longitudinal rows of long, stout setae and many smaller and finer setae near the gymnoparia. Laeotorma short with pternotorma present. Dexiotorma long ( $1 / 5$ length of the base of epipharynx), pternotorma present. Haptomeral region with slightly curved, transverse row of 12-17 heli above which are 7 sensilla. Haptolachus with 4 sensilla ( 2 at base, 2 at left margin). Sensorial cone present. Sclerotized plate and crepis absent. Mandibles (Figs 12-13). Asymmetrical, with 2 scissorial teeth anterior to notch; 2 posterior to notch on left mandible, and 1 posterior to notch on right mandible. Scissorial teeth of left mandible $\mathrm{S}_{3}$ and $\mathrm{S}_{4}$ welldeveloped. Stridulatory area elongate-oval with 30 stridulatory ridges (Fig. 10). Dorsal surface with 2 setae near the proximal end of the scissorial area and 6-7 dorsomolar setae. Basomedial angle with brustia of 8-10 short setae. Maxilla (Fig. 11). Galea and lacinia fused forming mala. Mala with large uncus at apex and 2 subterminal unci fused at base. Stridulatory area consisting of a row of 5-6 acute teeth and 2 small anterior conical processes. Labium (Fig. 9). Hypopharyngeal sclerome with welldeveloped truncate process on right side. Glossa with 3-5 setae set in 2 rows on each side; base with transverse row of 10-14 short setae; apex with 4-5 sensilla. Lateral lobe with 8-10 setae on each side. Antenna (Fig. 3). 4-segmented. Apical segment with 2 dorsal and 3 ventral sensory spots (1 lateroexternal and 1 laterointernal). 

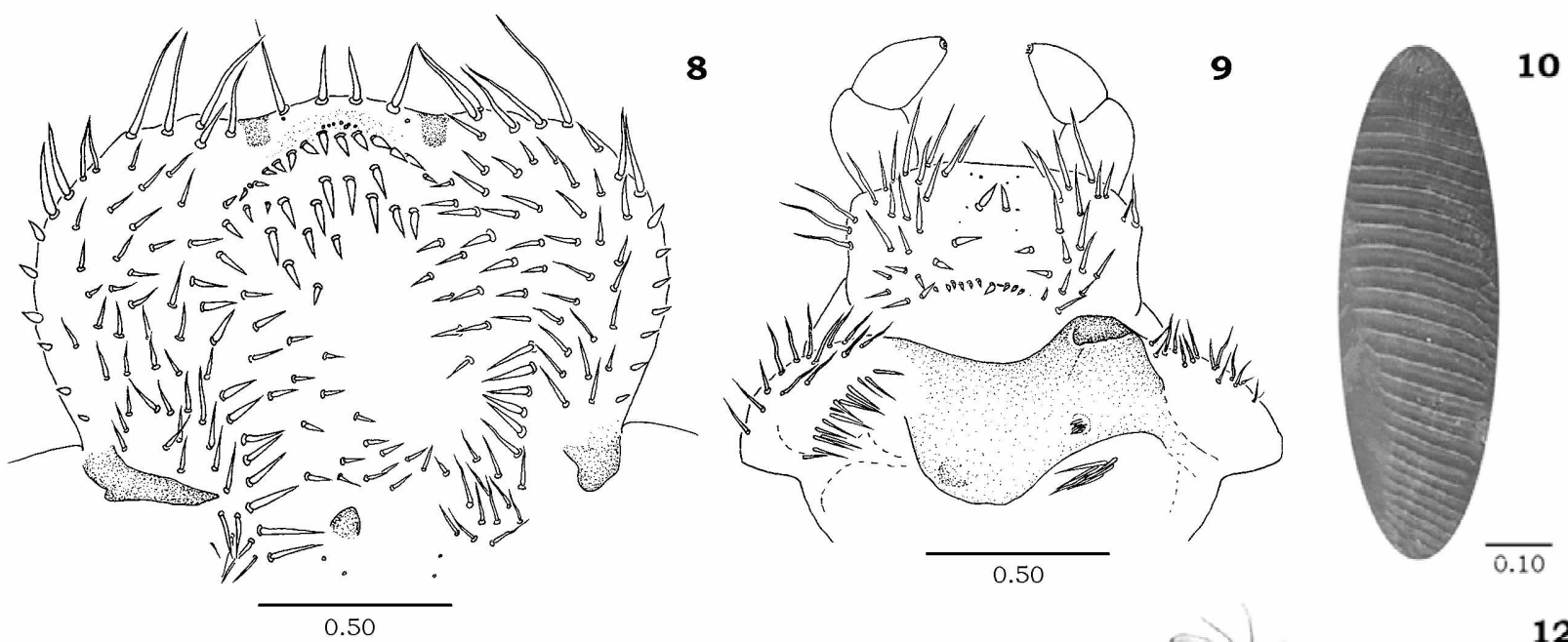

11

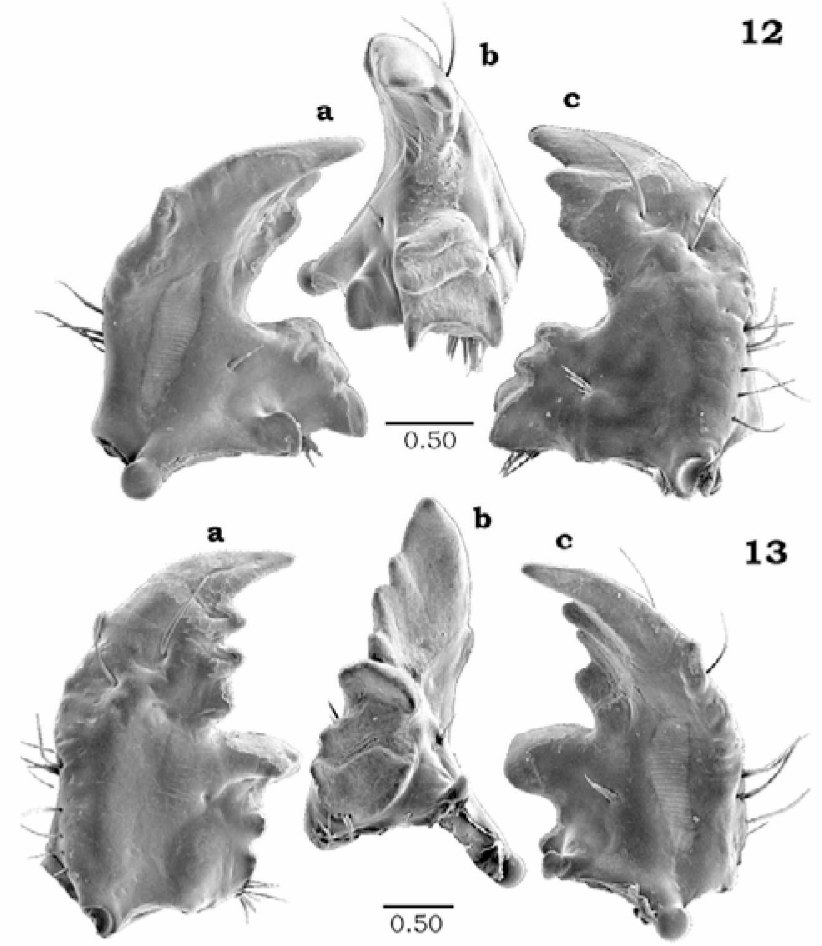

Figs 8-13. Netocia morio third-instar larva. 8 - epipharynx; 9 - hypopharynx; 10 - detail of stridulatory area of mandibles; 11 ventral (a) and dorsal (b) view of maxilla; 12 - ventral (a), lateral (b) and dorsal (c) view of right mandible; 13 - dorsal (a), lateral (b) and ventral (c) view of left mandible.

Thorax. Dorsa of thoracic segments with $1-4$ rows of short setae, each posterior row with long to short setae. Spiracles (Fig. 6). Thoracic spiracles with 26 holes across diameter. Legs. Tarsunguli cylindrical bearing 11-12 setae (Fig. 4).

Abdomen. Abdominal spiracles similar in size. Dorsa of abdominal segments I-VIII with 3-4 rows of short setae, each posterior row with long to short setae. Abdominal segments IX-X fused, densely setose with short setae and single row of long to short setae at the middle and apex (Fig. 1). Tegilla composed of short, acute setae and sparse long straight setae. Lower anal lip with many short and curved setae and 2-3 transversal rows of long, acute setae (Fig. 5). Raster with a pair of palidia joined anteriorly; each palidium consisting of
11-15 short pali. Apex of pali round and flattened (Fig. 7).

\section{Netocia oblonga (Gory \& Percheron, 1833) third instar larva}

(Figs 14-26)

The larval description is based on seven third instar larvae collected from ant nests at Sierra de Gador, Almeria (Spain), X-1997, Micó leg.; eight third instar larvae collected from soil surrounding root system of Lamiaceae at Sierra de Gador, Almeria (Spain), II-1999, Micó leg.; two third instar larvae collected from a rabbit latrine at El Bonillo, Albacete (Spain), II-1996, Micó \& Verdú leg; three third instar larvae collected from soil surrounding root system of Lamiaceae at Bonete, Albacete (Spain), II-1998, Micó \& Verdú leg.; one third 

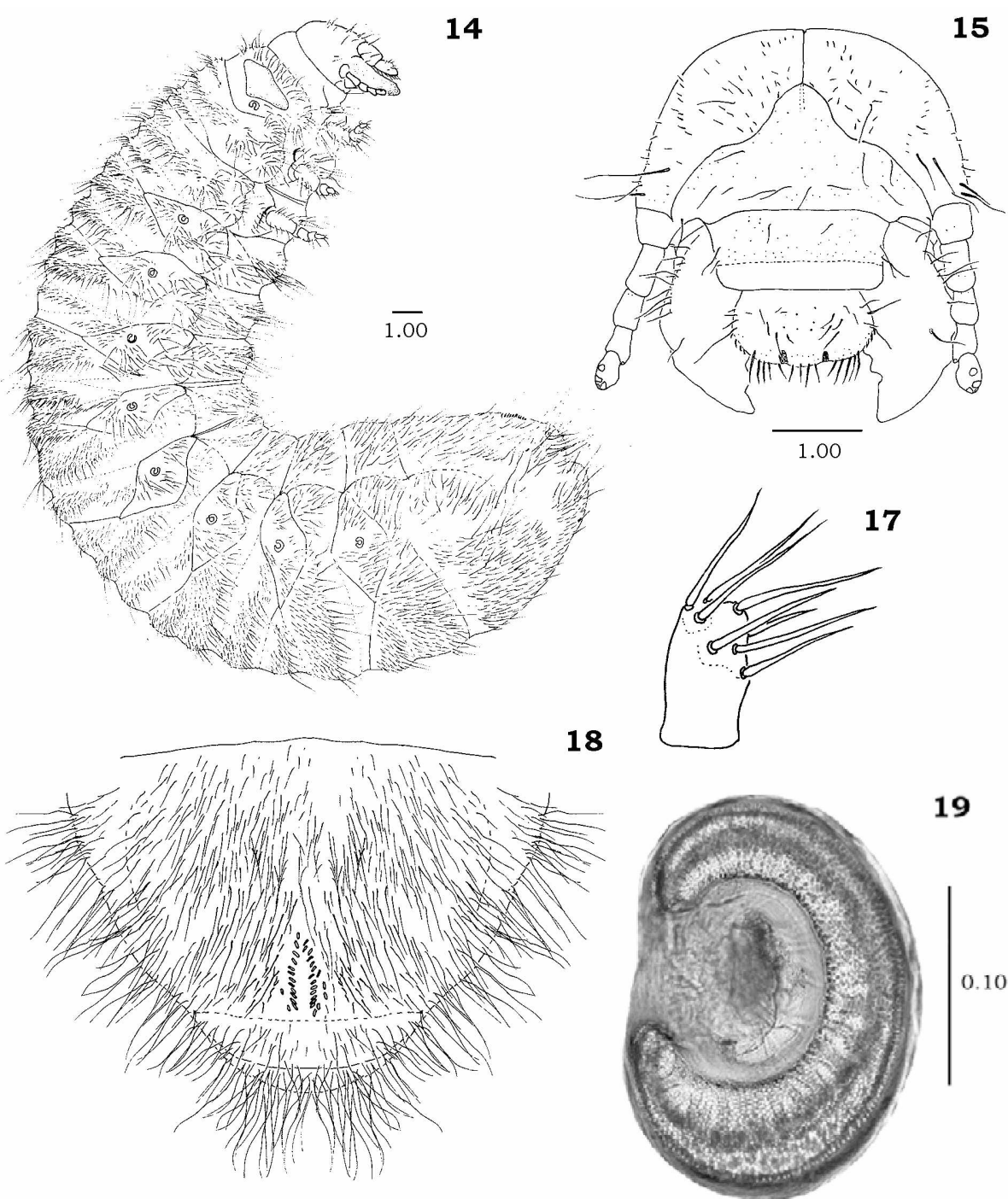

15

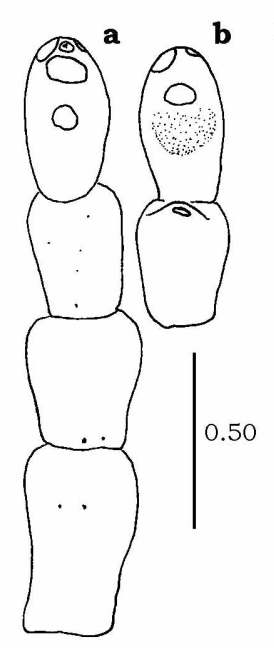

16
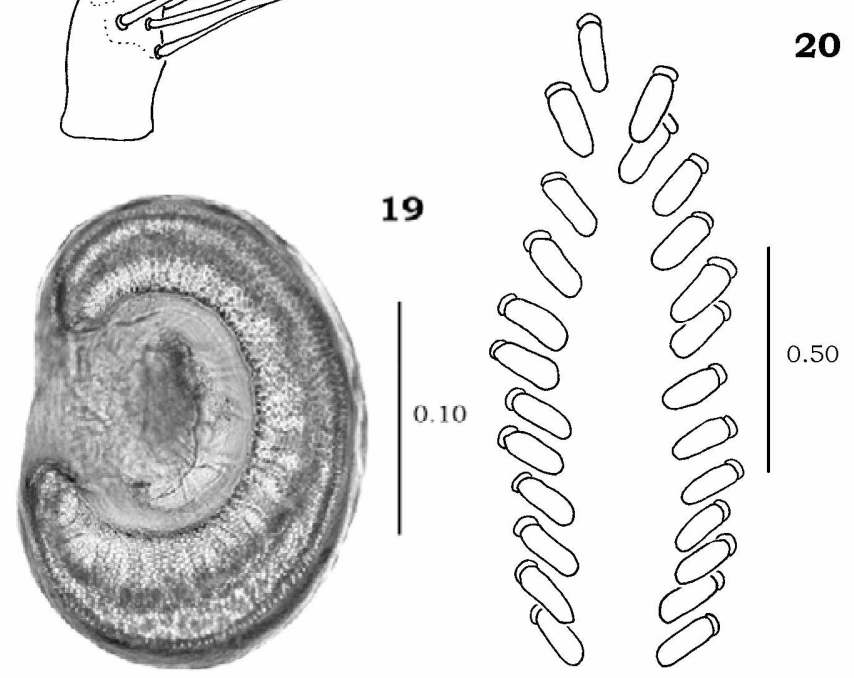

Figs 14-20. Netocia oblonga third-instar larva. 14- habitus; 15 - frontal view of head; 16 - dorsal (a) view of antenna and ventral (b) view of apical antennal segment showing sensory spots; 17 - tarsungulus of prothoracic leg; 18 - venter of last abdominal segment; 19 - prothoracic spiracle; 20 - detail of palidium.

instar larvae reared from eggs laid by adults collected at Royuelos, Teruel (Spain), VII-1997, Micó, Galante \& Verdú leg.

Head. Maximum width of head capsule $4.5 \mathrm{~mm}$. Cranium (Fig. 15). Colour light yellow. Dorsoepicranium with 25-30 unordered short setae and 1 long seta on each side. Frons sparsely punctate, with 1-3 anterior setae, 1 posterior seta, 1 external seta and 1 anterior angle setae on each side. Labrum (Fig. 15). Trilobed, narrower than clypeus; clithra present. Epipharynx (Fig. 21). Plegmatium absent. Corypha with 4 long setae flanked by $2-3$ sensilla on each side. Acanthoparia with 7-12 short setae, decreasing in size posteriorly. Chaetoparia welldeveloped, covered with longitudinal rows of long, stout setae and many finer setae near the gymnoparia. Laeotorma short with pternotorma present. Dexiotorma long (1/5 length of the base of epipharynx), pternotorma present. Haptomeral region with slightly curved, transverse row of 12-14 heli above which are 5-9 sensilla.
Haptolachus with 4 sensilla ( 2 at base, 2 at left margin). Sensorial cone present. Sclerotized plate and crepis absent. Mandibles (Fig. 25-26). Asymmetrical, with 2 scissorial teeth anterior to notch; 2 posterior to notch on left mandible and 1 posterior to notch on right mandible. Scissorial teeth of left mandible $\mathrm{S}_{3}$ and $\mathrm{S}_{4}$ well-developed. Stridulatory area elongate-oval with 20 stridulatory ridges (Fig. 23). Dorsal surface with 2 setae near the proximal end of the scissorial area and 6-7 dorsomolar setae. Basomedial angle with brustia of 8-10 short setae. Maxilla (Fig. 24). Galea and lacinia fused forming mala. Mala with large uncus at apex and 2 subterminal unci fused at base. Stridulatory area consisting of a row of 5-8 acute teeth and 1 small anterior conical process. Labium (Fig. 22). Hypopharyngeal sclerome with well-developed truncate process on right side. Lateral lobe with 8-10 setae on each side. Glossa with $3-5$ setae set in 2 rows on each side; base with transverse row of 10-14 short setae; apex with 4-5 sensilla. Antenna (Fig. 16). 4-segmented. Apical 

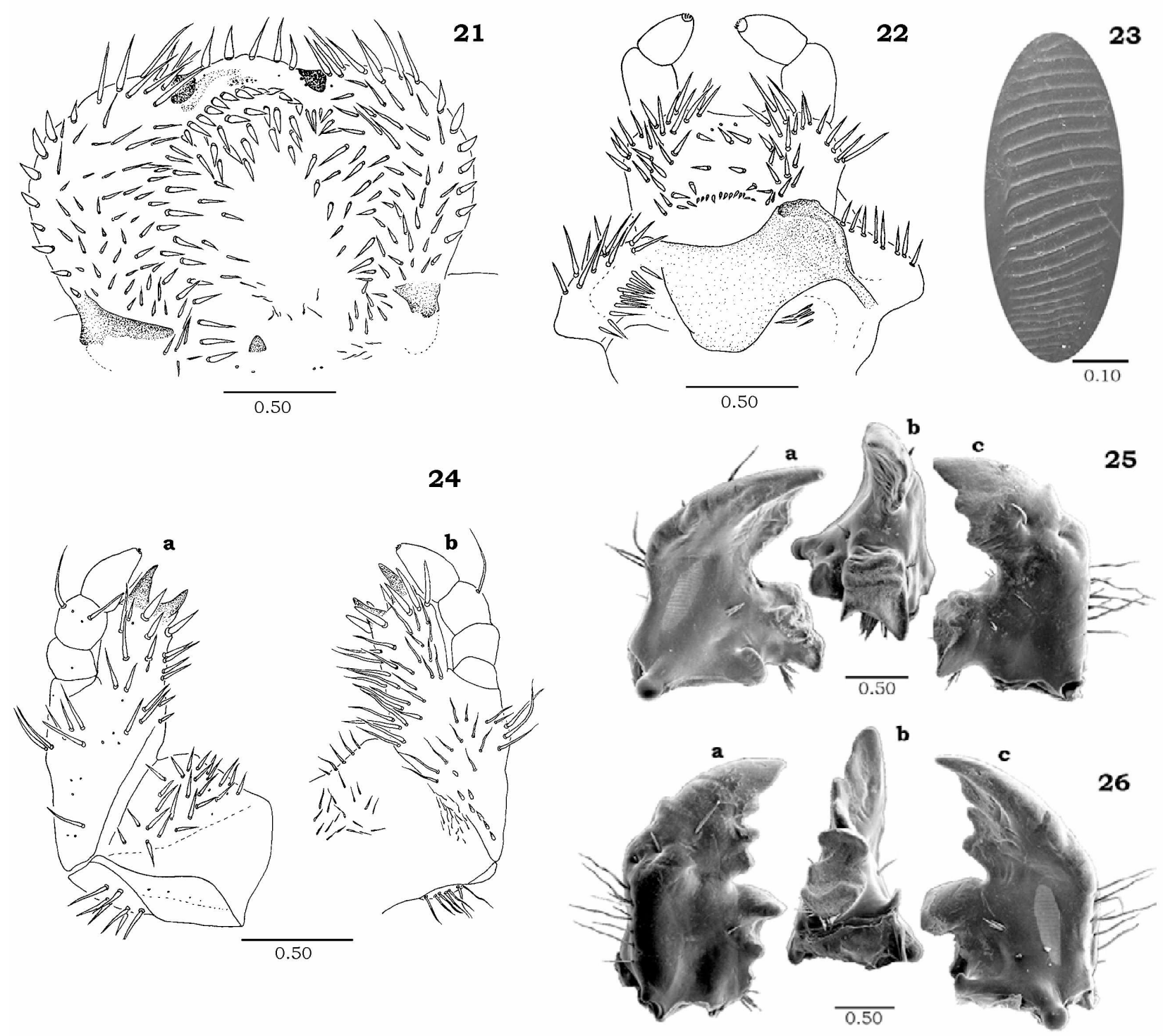

Figs 21-26. Netocia oblonga third-instar larva. 21 - epipharynx; 22 - hypopharynx; 23 - detail of stridulatory area of mandibles; 24 - ventral (a) and dorsal (b) view of maxilla; 25 - ventral (a), lateral (b) and dorsal (c) view of right mandible; 26 - dorsal (a), lateral (b) and ventral (c) view of left mandible.

segment with 2 dorsal and 3 ventral sensory spots (1 lateroexternal, and 1 laterointernal).

Thorax. Dorsa of thoracic segments with 1-3 rows of short setae, each posterior row with long to short setae. Spiracles (Fig. 19).Thoracic spiracle with 20 holes across diameter. Legs. Tarsunguli cylindrical bearing 11-12 setae (Fig. 17).

Abdomen. Spiracles of abdominal segments I-VII similar in size, those of VIII smaller. Dorsa of abdominal segments I-VIII with 4-6 rows of short setae, each posterior row with long to short setae. Abdominal segments IX-X fused, densely setose with short and long setae (Fig. 14). Tegilla composed of a single row of short setae on each side of palidium and many rows of longer straight, acute setae. Lower anal lip with many short and curved setae and 1 transverse row of long, acute setae at apex (Fig. 18). Raster with a pair of palidia joined anteriorly; each palidium consisting of 11-15 short pali. Apex of pali round and flattened (Fig. 20).

\section{Potosia cuprea brancoi Baraud, 1992 third instar larva}

(Figs 27-39)

The larval description is based on 4 third instar larvae reared from eggs laid by adults collected at Vall d'Ebo, Alicante (Spain), IV-1997, Micó \& Verdú leg.; eight third instar larvae reared from eggs laid by adults collected at El Garbinet, Alicante (Spain), V-2000, Micó \& Verdú leg.

Head. Maximum width of head capsule $4.3 \mathrm{~mm}$. Cranium (Fig. 28). Colour light yellow. Dorsoepicranium with 2 groups of short setae more or less arranged in 2 rows on each side; normally with 1 long seta on each side. Frons moderately punctate, with 1 posterior seta and 1 anterior angle seta on each side; anterior and external setae reduced to a single microseta on each side. Clypeus 

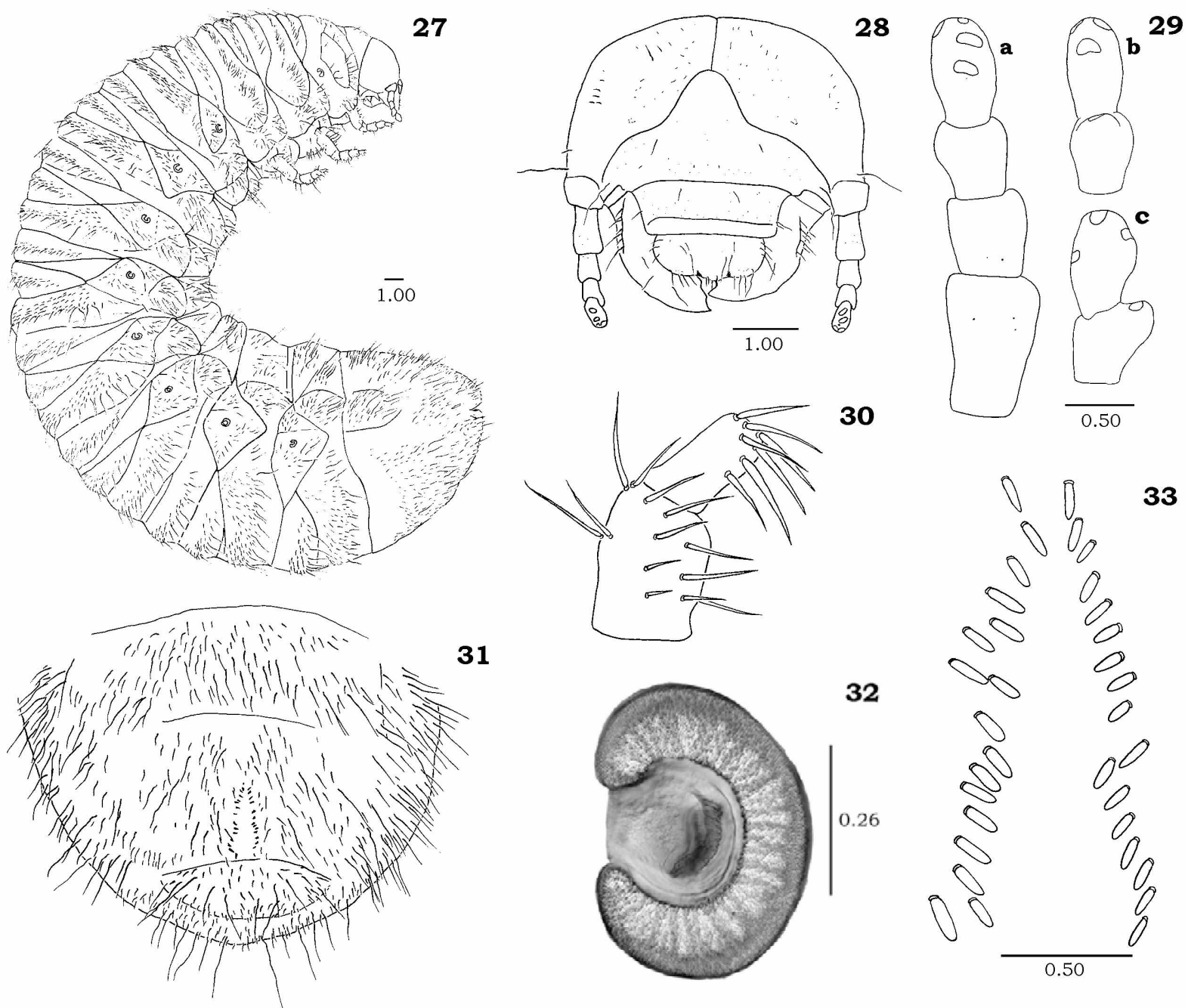

30
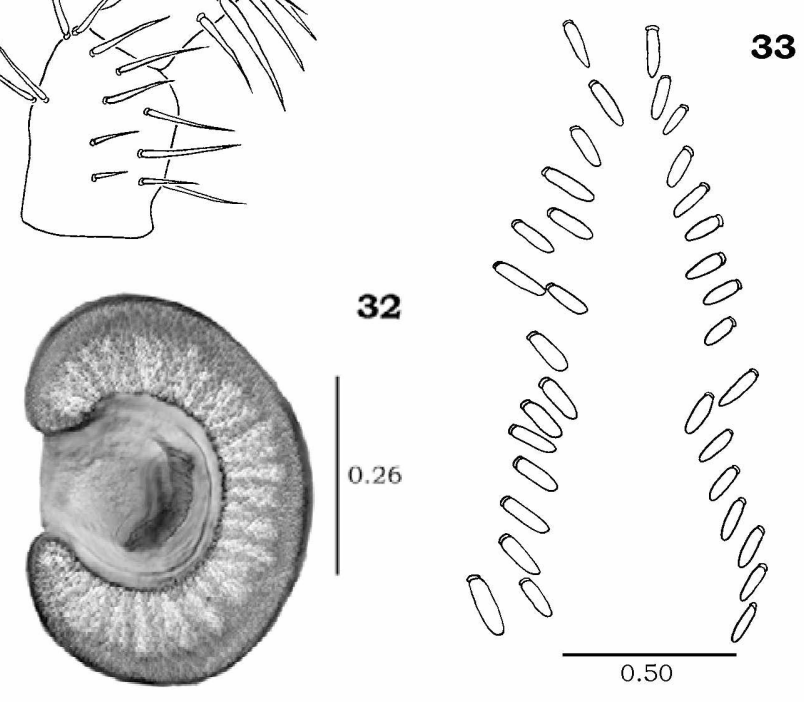

Figs 27-33. Potosia cuprea third-instar larva. 27- habitus; 28 - frontal view of head; 29 - dorsal (a) view of antenna, ventral (b) and lateral (c) view of apical antennal segment showing sensory spots; 30 - detail of tarsungulus and tibiae of prothoracic leg; 31 venter of last abdominal segment; 32 - prothoracic spiracle with detail of respiratory plate; 33 - detail of palidium.

with 2 anterior setae and 2 external setae on each side. Postclipeus moderately punctate. Labrum (Fig. 28). Trilobed, narrower than clypeus; clithra present. Epipharynx (Fig. 34). Plegmatium absent. Corypha with 4 long setae flanked by $2-3$ sensilla on each side. Haptomeral region with slightly curved, transverse row of 15-18 heli above which are 7-9 sensilla. Acanthoparia with 7-9 short, stout setae, decreasing in size posteriorly. Chaetoparia welldeveloped, covered with longitudinal rows of long, stout setae and many smaller and finer setae near the gymnoparia. Laeotorma short with pternotorma present. Dexiotorma long ( $1 / 3$ length the base of epypharinx), pternotorma short or absent. Haptolachus with 4 sensilla ( 2 on the base, 2 on left margin). Sensorial cone present. Sclerotized plate and crepis absent. Mandibles (Figs 38-39). Asymmetrical, with 2 scissorial teeth anterior to notch; 2 posterior to notch on left mandible, and 1 posterior to notch on right mandible. Scissorial tooth of left mandible $S_{3}$ conspicuously reduced and widely separated from $S_{4}$ tooth. Stridulatory area elongate-oval consisting of 24-25 transverse ridges; inter-ridge area 5 to 8 times ridge width (Fig. 36). Dorsal surface with 2 setae near the proximal end of the scissorial area and 6-7 dorsomolar setae. Basomedial angle with brustia of short setae. Maxilla (Fig. 37). Galea and lacinia fused forming mala. Mala with large uncus at apex and 2 subterminal unci fused at base. Stridulatory area consisting of a row of 5-7 acute teeth and 1 small anterior conical process. Labium (Fig. 35). Hypopharyngeal sclerome with well-developed truncate process on right side. Glossa with 3-5 setae set in 2 rows on each side; apex with 6-7 sensilla; base with transverse row of 10-14 short setae. Lateral lobe with 10-11 setae on each side. Antenna (Fig. 29). 4-segmented. Apical segment with 2 dorsal sensory spots and 3 ventral sensory spots (1 lateroexternal and 1 laterointernal).

Thorax. Dorsa of thoracic segments with 1-4 rows of short setae, each posterior row with long to short setae. Spiracle. Thoracic spiracle with 22-29 holes across diameter. Lobes of respiratory plate almost equal (Fig. 32). Legs. Tarsunguli cylindrical bearing 10-11 setae (Fig. 30). 

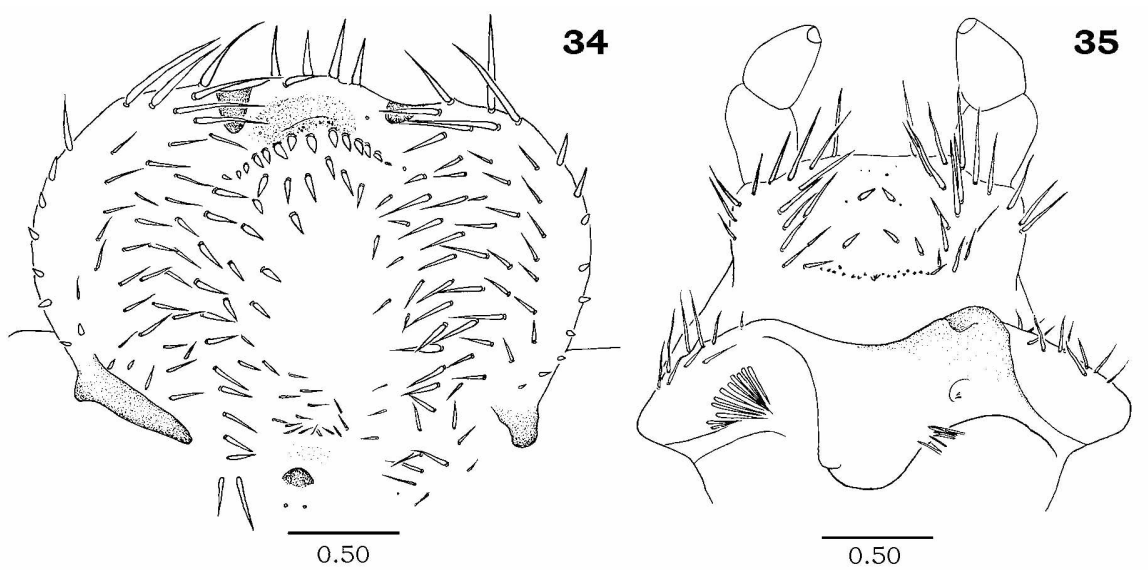

35
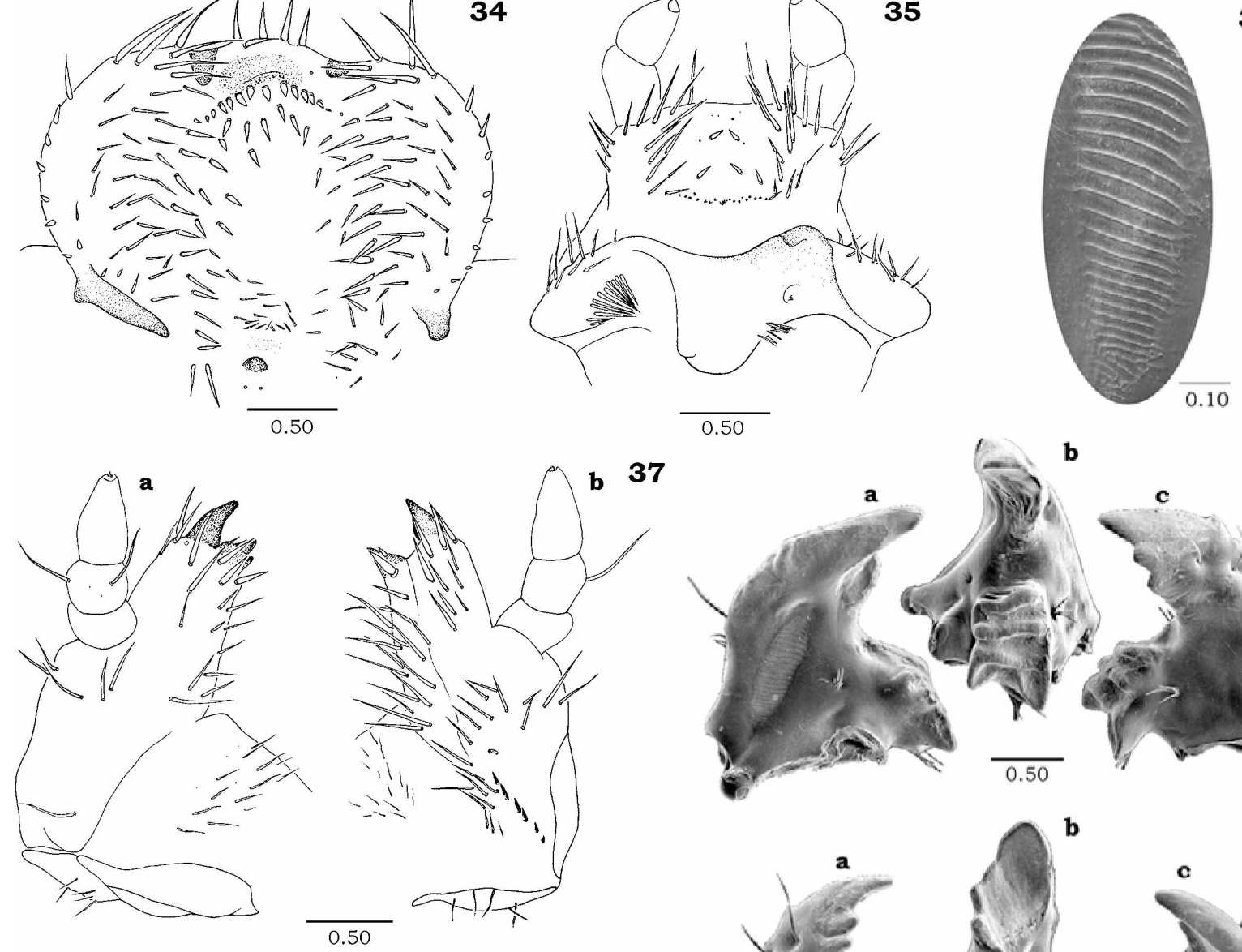

b

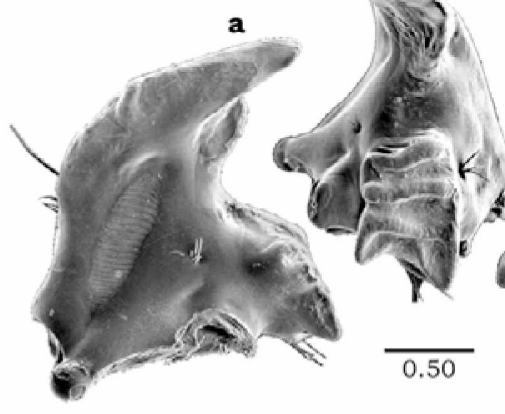

c

38

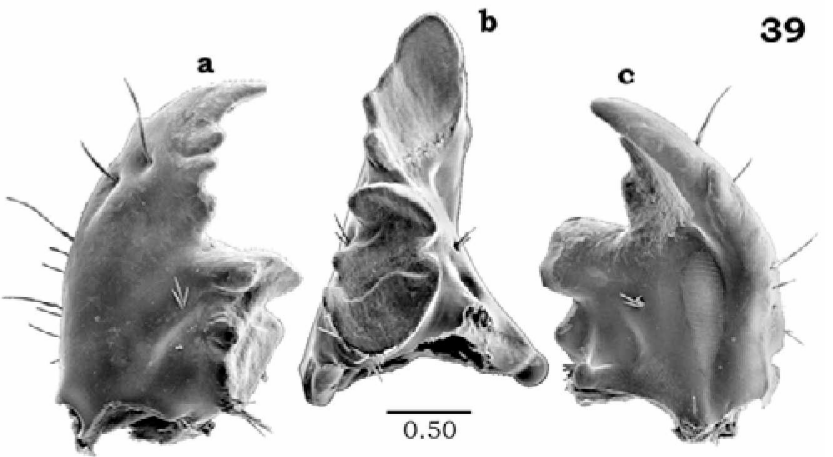

Figs 34-39. Potosia cuprea third-instar larva. 34 - epipharynx; 35 - hypopharynx; 36 - detail of stridulatory area of mandibles; 37 - ventral (a) and dorsal (b) view of maxilla; 38 - ventral view (a), lateral view (b) and dorsal view (c) of right mandible; 39 dorsal view (a), lateral view (b) and ventral view (c) of left mandible.

Abdomen. Abdominal spiracles similar in size. Dorsa of abdominal segments I-VIII with 3-4 rows of short setae, each posterior row with long to short setae. Abdominal segments IX-X fused, densely setose with short setae and a single row of long to short setae in the middle and at the apex (Fig. 27). Tegilla composed of short, acute setae and sparse long setae. Lower anal lip with many short and curved setae and 1 transverse row of long, acute setae (Fig. 31). Raster with a pair of palida joined anteriorly and slightly diverging posteriorly. Each palidium consisting of 14-17 pali. Apex of pali acute and flattened (Fig. 33).

\section{Potosia opaca (Fabricius, 1787) third instar larva}

(Figs 40-52)

The larval description is based on 9 third instar larvae reared from eggs laid by adults collected at El Garbinet, Alicante (Spain), V-2000, Micó \& Verdú leg.
Head. Maximum width of head capsule 4.6-4.9 mm. Cranium (Fig. 41). Colour light yellow. Dorsoepicranium with 2 groups of short setae more or less arranged in 2 rows on each side; normally with 1 long seta on each side. Frons moderately punctate, with 1 posterior seta and 1 anterior angle seta on each side; anterior and external setae reduced to single microseta on each side. Clypeus with 2 anterior setae and 2 external setae on each side. Postclypeus moderately punctate. Labrum (Fig. 41). Trilobed, narrower than clypeus; clithra present. Epipharynx (Fig. 47). Plegmatium absent. Corypha with 4 long setae flanked by $2-3$ sensilla on each side. Haptomeral region with slightly curved, transverse row of $15-18$ heli above which are 7-9 sensilla. Acanthoparia with 7-9 short and stout setae, decreasing in size posteriorly. Chaetoparia well-developed, covered with longitudinal rows of long, stout setae and many smaller and finer setae near the gymnoparia. Laeotorma short with pternotorma present. 

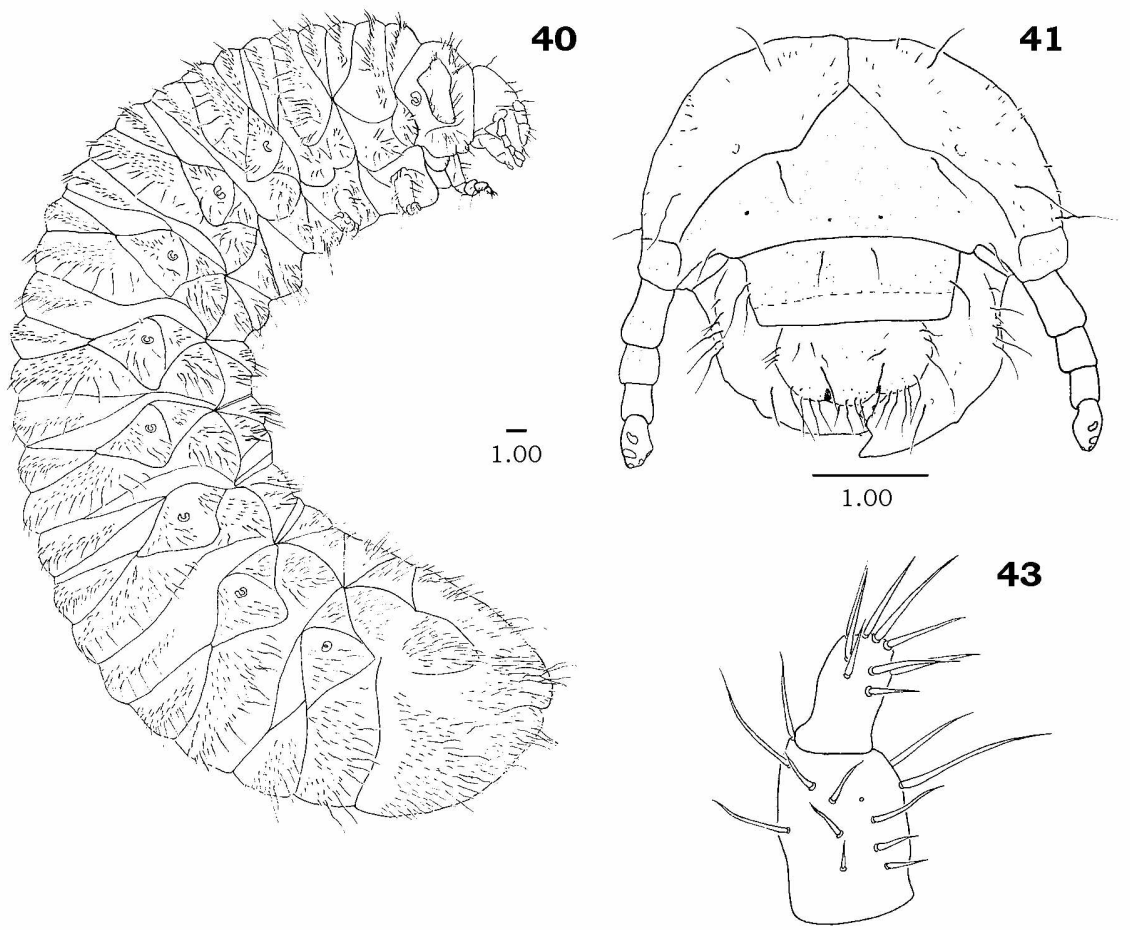

44

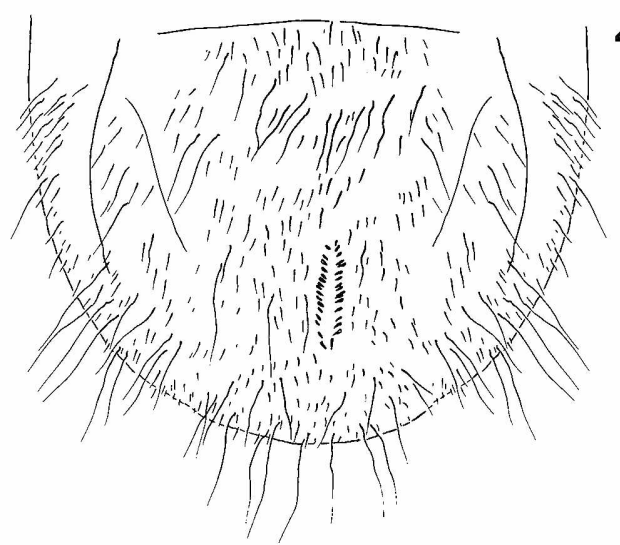

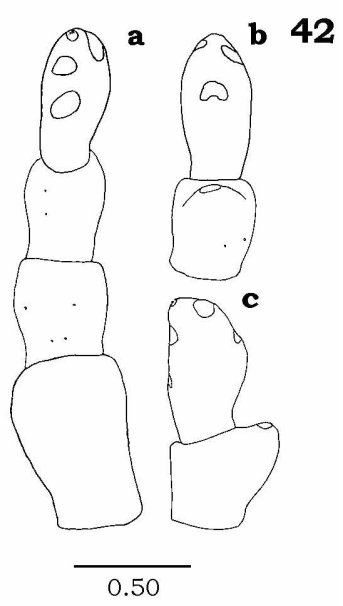

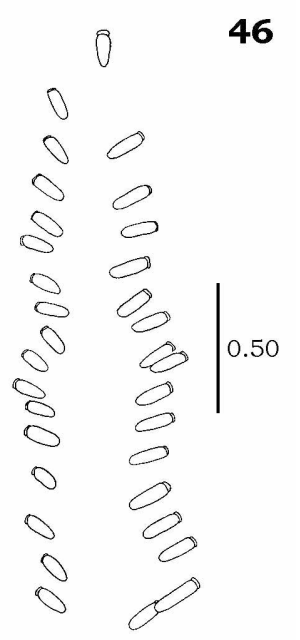

Figs 40-46. Potosia opaca third-instar larva. 40- habitus; 41 - frontal view of head; 42 - dorsal (a) view of antenna, ventral (b) and lateral (c) view of apical antennal segment showing sensory spots; 43 - detail of tarsungulus and tibiae of prothoracic leg; 44 venter of last abdominal segment; 45 - prothoracic spiracle with detail of respiratory plate; 46 - detail of palidium.

Dexiotorma long (1/3 length base of epipharynx), pternotorma short or absent. Haptolachus with 4 sensilla ( 2 on the base, 2 on left margin). Sensorial cone present. Sclerotized plate and crepis absent. Mandibles (Figs 51-52). Asymmetrical, with 2 scissorial teeth anterior to notch; 2 posterior to notch on left mandible, and 1 posterior to notch on right mandible. Scissorial tooth of left mandible $\mathrm{S}_{3}$ conspicuously reduced and widely separated from $\mathrm{S}_{4}$ tooth. Stridulatory area elongated-oval consisting of 15-19 transverse ridges; inter-ridge area 1.7-2 times ridge width (Fig. 49). Dorsal surface with 2 setae near proximal end of scissorial area and 6-7 dorsomolar setae. Basomedial angle with brustia of short setae. Maxilla (Fig. 50). Galea and lacinia fused forming mala. Mala with large uncus at apex and 2 subterminal unci fused at base. Stridulatory area consisting of a row of 4-5 acute teeth and 1 small anterior conical process. Cardo with 7-8 setae. Labium (Fig. 48). Hypopharyngeal sclerome with well-developed truncate process on right side. Glossa with $3-5$ setae set in 2 rows on each side; base with transverse row of 10-14 short setae; apex with 8-9 sensilla. Lateral lobe with 13-15 setae on each side. Antenna (Fig. 42). 4-segmented. Apical segment with 2 dorsal and 3 ventral sensory spots (1 lateroexternal, and 1 laterointernal). Legs. Tarsunguli cylindrical bearing 10-11 setae (Fig. 43).

Thorax. Dorsa of thoracic segments with 1-4 rows of short setae, each posterior row with long to short setae. Spiracles. Thoracic spiracle (Fig. 45) with 26-30 holes across diameter. Respiratory plate with superior lobe slightly larger than inferior lobe.

Abdomen. Abdominal spiracles similar in size. Abdominal segments I-VIII with 3-4 rows of short setae, each posterior row with long to short setae. Abdominal 

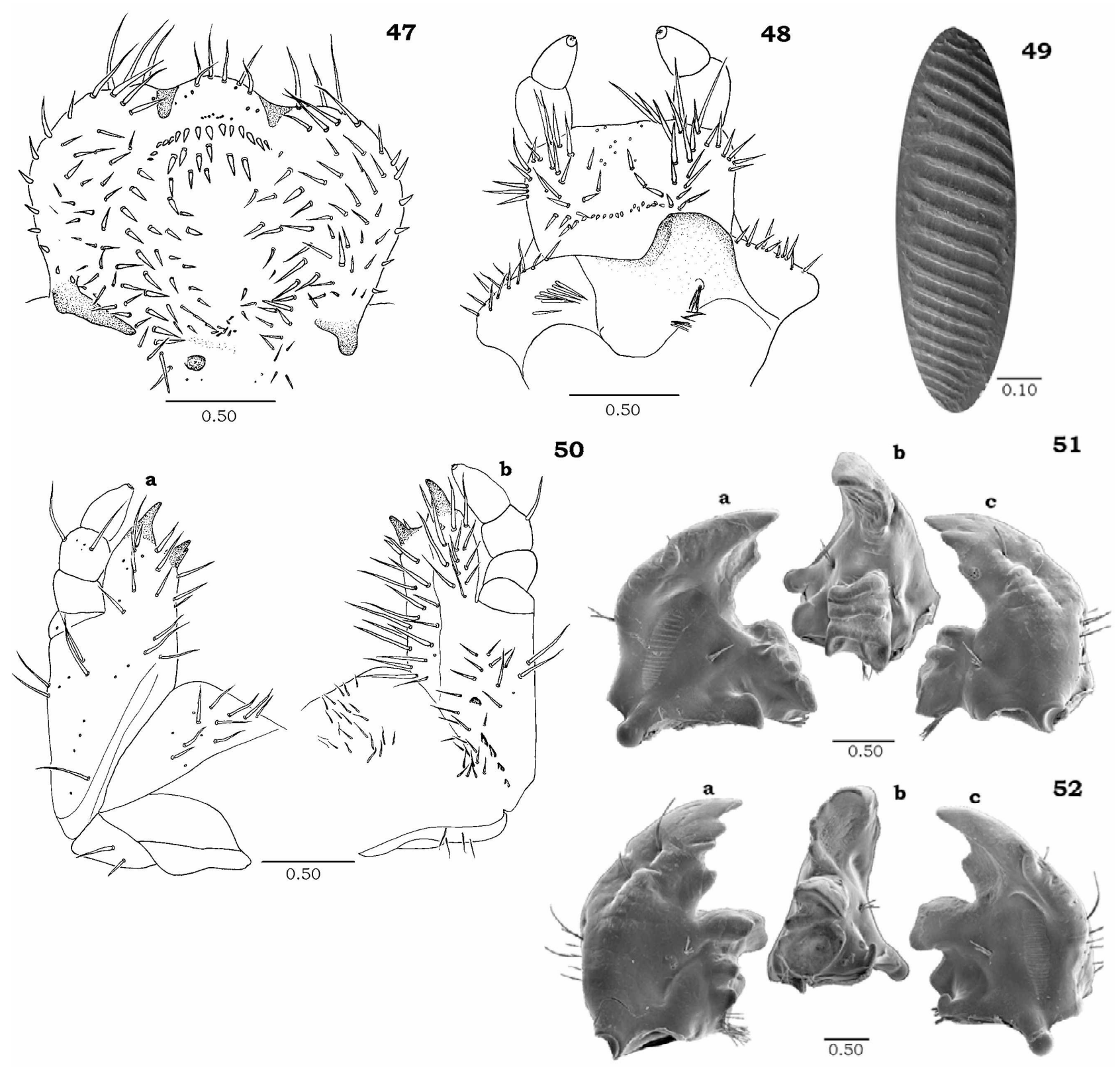

Figs 47-52. Potosia opaca third-instar larva. 47 - epipharynx; 48 - hypopharynx; 49 - detail of stridulatory area of mandibles; 50 - ventral (a) and dorsal (b) view of maxilla; 51 - ventral (a), lateral (b) and dorsal (c) view of right mandible; 52 - dorsal (a), lateral (b) and ventral (c) view of left mandible.

segments IX-X fused, densely setose with short setae and a single row of long to short setae in the middle and at the apex (Fig. 40). Tegilla composed of short, acute setae and sparse long setae. Lower anal lip with many short and curved setae and 1 transverse row of long, acute setae (Fig. 44). Raster with a pair of palida joined anteriorly and slightly or non-diverging posteriorly. Each palidium consisting of 15-19 pali. Apex of pali acute and flattened (Fig. 46).

\section{KEY TO N. MORIO, N. OBLONGA, P. CUPREA BRANCOI} AND $P$. OPACA THIRD INSTAR LARVAE

The following key provides the diagnostic characteristics of the above four species.
1. Head with anterior frontal setae and external frontal setae reduced to microsetae or absent (Figs 28, 41). Raster with pali acute at apex (Figs 33,46) . ............ 2

1 '. Head with anterior frontal setae and external frontal setae medium to long (Figs 2, 15). Raster with pali round at apex

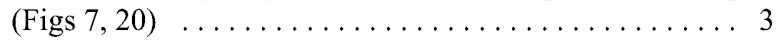

2. Stridulatory area of mandibles consisting of $24-25$ transverse ridges; inter-ridge area 5-8 times the ridge width (Fig. 36) . ................. Potosia cuprea brancoi Baraud

2'. Stridulatory area of mandibles consisting of 15-19 transverse ridges; inter-ridge area 1.7-2 times the ridge width (Fig. 49) ................ Potosia opaca Fabricius

3. Frons with 1 anterior seta on each side. Tegilla with short setae and isolated long setae (Fig. 5) ............... ................... Netocia morio (Fabricius)

3'. Frons with 1-3 anterior setae on each side. Tegilla with many long setae and few short setae (Fig. 18) ......... ............. Netocia oblonga (Gory \& Percheron) 


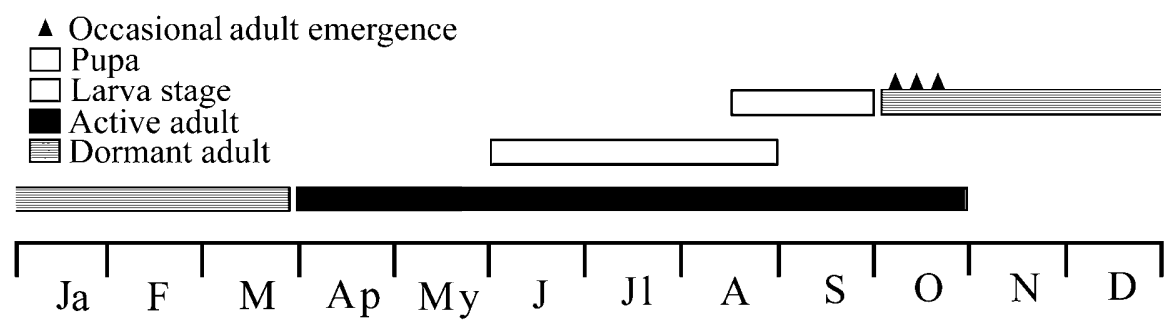

Fig 53. Diagram illustrating the life cycle of Netocia morio, Potosia cuprea brancoi and P. opaca under laboratory conditions.

\section{Notes on biology}

Immature stages of these species were found in organic substrates such as vegetable matter in soil surrounding root systems of plants, ant nests, rabbit latrines and wood (Table 1). Our field observations showed that $P$. cuprea brancoi and P. opaca occur in decaying wood of Ficus carica L., Ceratonia siliqua L. and Phoenix dactilifera L., where they consume the wood and promote more rapid decay. In contrast, Netocia species deposit their eggs in rich organic soil close to organic matter (e.g. piles of rabbit dung and piles of debris close to ant nests) and I deep inorganic soil (Table 1).

In the laboratory, P. cuprea brancoi, $P$. opaca and $N$. morio larvae feed on ripe fruit, whereas $N$. oblonga was unable to exploit this resource. The results showed that species feeding on ripe fruit completed their life cycle in 2-3 months (Fig. 53), and normally overwinter as an adult. In contrast, field observations showed that, in many cases, these species overwinter as larvae (Table 1).
Netocia oblonga has a life cycle of 1-2 years and overwinter as larvae.

\section{DISCUSSION}

\section{Larval morphology}

The morphology of the larvae differ sufficiently to support the validity of genus status for both Netocia and Potosia. Characters supporting this differentiation are the shape of the pali (Figs 7, 20,33,46) and the form and disposition of the scissorial teeth on left mandible (Figs $13,26,39,52)$. Pali are round at apex in Netocia and pointed in Potosia. The anterior frontal setae are reduced to microsetae in Potosia, Liocola, Cetonischema and Cetonia Fabricius, 1775 species (Medvedev, 1952), whereas the Netocia species described here and those illustrated by Medvedev (1952, 1964), such as N. hungarica (Herbts, 1790), N. karelini (Zoubkoff, 1829) and $N$. trojana (Gory \& Percheron, 1833), have welldeveloped anterior setae. Netocia was traditionally sepa-

TABLE 1. Field records of the different substrates in which immature stages of Netocia and Potosia were found.

\begin{tabular}{|c|c|c|c|c|c|}
\hline Species & Stage & Substrate & Date & Localities & Leg. \\
\hline & immature & $\begin{array}{c}\text { Oryctolagus cuniculus (L.) } \\
\text { latrine }\end{array}$ & $13-4-1996$ & $\begin{array}{l}\text { La Carrasqueta, Alcoy } \\
\text { (Alicante, Spain) }\end{array}$ & Micó \& Verdú \\
\hline \multirow[t]{4}{*}{$\begin{array}{l}\text { Netocia morio } \\
\text { (Gory \& Percheron) }\end{array}$} & L3 & O. cuniculus latrine & $15-4-1998$ & $\begin{array}{l}\text { La Carrasqueta, Alcoy } \\
\text { (Alicante, Spain) }\end{array}$ & Micó \& Verdú \\
\hline & $\mathrm{L} 3$ & Cistaceae root system & $15-3-1998$ & $\begin{array}{l}\text { La Carrasqueta, Alcoy } \\
\text { (Alicante, Spain) }\end{array}$ & Micó \\
\hline & L3 & Thatch of abandoned ant nest & $26-10-1997$ & Fondón (Almería, Spain) & Micó \\
\hline & $\mathrm{L} 2 \& \mathrm{~L} 3$ & Labiatae root system & $26-10-1997$ & Almocita (Almería, Spain) & Micó \\
\hline \multirow{5}{*}{$\begin{array}{l}\text { Netocia oblonga } \\
\text { (Gory \& Percheron) }\end{array}$} & L3 & Labiatae root system & $7-4-1999$ & Almocita (Almería, Spain) & Micó \\
\hline & L3 & O. cuniculus latrine & $22-2-1998$ & El Bonillo (Albacete, Spain) & Micó \& Verdú \\
\hline & $\mathrm{L} 2$ & under stone & 7-4-1999 & El Bonillo (Albacete, Spain) & Micó \& Verdú \\
\hline & L3 & Ficus carica L. living tree & $26-4-1996$ & Vall d'Ebo (Alicante, Spain) & Micó \& Verdú \\
\hline & $\mathrm{L} 2 \& \mathrm{~L} 3$ & $\begin{array}{l}\text { Phoenix dactilifera L. living } \\
\text { tree }\end{array}$ & $3-8-1997$ & Elche (Alicante, Spain) & Isidro \\
\hline \multirow{5}{*}{$\begin{array}{l}\text { Potosia cuprea brancoi } \\
\text { Baraud }\end{array}$} & $\mathrm{L} 2 \& \mathrm{~L} 3$ & $P$. dactilifera living tree & 2-12-1999 & San Vicente (Alicante, Spain) & Micó \& Falcó \\
\hline & L3 & P. dactilifera living tree & $3-2-2000$ & San Juan (Alicante, Spain) & - \\
\hline & $\mathrm{L} 2 \& \mathrm{~L} 3$ & P. dactilifera living tree & $5-4-2000$ & Alicante (Spain) & - \\
\hline & L3 & $\begin{array}{c}\text { Ceratonia siliqua } \mathrm{L} \text {. living } \\
\text { tree }\end{array}$ & $10-10-2001$ & Novelda (Alicante, Spain) & - \\
\hline & L3 & P. dactilifera living tree & $3-8-1997$ & Elche (Alicante, Spain) & Isidro \\
\hline \multirow[t]{2}{*}{ Potosia opaca (F.) } & L2 \& L3 & P. dactilifera living tree & $2-12-1999$ & San Vicente (Alicante, Spain) & Micó \& Falcó \\
\hline & $\mathrm{L} 2 \& \mathrm{~L} 3$ & P. dactilifera living tree & $5-4-2000$ & Alicante (Spain) & - \\
\hline
\end{tabular}


rated from other related genera because the mesometasternal apofisis in adults is setose and densely punctate. However, the systematic position of both genera remained unresolved. Our results show that larval morphology supports the separation of both genera.

Several diagnostic characters such as the number of frontal setae, body vestiture, and the shape of thoracic spiracles distinguish $N$. morio from $N$. oblonga. On the contrary, the morphology of $P$. cuprea brancoi and $P$. opaca was very similar. Both species are parapatric and exploit the same trophic resource, and their larvae normally coexist. In this case, the stridulatory area of mandibles was the most reliable character for identify both species. The stridulatory area of mandibles was reported as a specific diagnostic character for closely related species, and may be related to intraspecific communication between larvae (Micó et al., 2001).

\section{Larval biology}

The larvae develop in moist organic substrates such as piles of descomposing vegetable matter, packrat dung middens, or ant nests (Wheeler, 1910; Paulian, 1959; Ritcher, 1966; Janssens, 1960; Hardy, 1988; Micó et al., 2000) and takes between 1-3 years. Nevertheless, there are few explicit descriptions of the larval biology of cetoniine species. Our field observations show that there are differences in the substrates exploited by the immature stages of the different species (Table 1). Potosia females laid their eggs in the hollows of branches and trunks of large trees. Such hollows are often full of soil and organic matter, however, larvae enter into close proximity with live wood. Palms are very commonly planted in the Southeastern Iberian Peninsula in gardens and are important commercially, the date-palm. Palms have closed tubular leaf sheaths. In the genus Phoenix L. the dorsal portion of a sheath is thickened whereas the remainder is fibrous, and the woody dorsal portion may persist as a stub on the trunk after a leaf in shed (Tomlinson, 1990). The soil and organic matter that accumulates between the sheath and trunk is a good substrate for oviposition. In the field larva faeces occur between the sheaths and the trunks, and burrows of Potosia larvae in the woody dorsal portion of leaf sheaths. Third instar larvae were found inside the trunks. However, the injury inflicted on trees tissue was not quantified.

Potosia immature stages are not only associated with decaying wood, as the larvae of $P$. cuprea have been found under the large debris piles of Formica rufa L. (Wheeler, 1910). In contrast, no larvae of Netocia were found in decaying wood. We found Netocia larvae feeding in rich organic soil surrounding plant root systems (Cistaceae, Lamiaceae), ant nests and rabbit latrines. Larvae of $N$. oblonga were found associated with abandoned ant nests. In this habitat they find the moist and organic substrates necessary for their development. Larval development does not depend on living ants, however, as the many reports indicate the larvae are part of the entomofauna associated with debris piles of ants (Wheeler, 1910; Ratcliffe, 1976; Hardy, 1988; Deloya \& Morón, 1994). The same optimal conditions occur in piles of rabbit dung. The European rabbit Oryctolagus cuniculus (L.) live in family groups, and dominant males delimit their territory daily by depositing dung latrines (Mykytowycz \& Gambale, 1969; Galante \& Cartagena, 1999). These piles of dung are a stable habitat rich in organic matter for larval development. The same occurs in the soil surrounding plant root systems, which are damp and rich in organic matter from the decaying leaves.

We conclude that moist accumulations of, organic matter are optimal for the development of Netocia and Potosia larvae, however, Potosia species are more generalist, and able to feed on wood in the Southeastern Iberian Peninsula.

Under laboratory conditions, the life cycle of $P$. cuprea brancoi, P. opaca, and N. morio lasted a few months, and they overwintered as adults (Fig. 53). Field observations showed that the same species could overwinter as third instar larvae. Temperature and the type of food resulted in the faster development under laboratory conditions, where ripe fruit was a rich resource for $P$. cuprea brancoi, $P$. opaca, and $N$. morio larvae. In spite of there being no difference in the mouth parts of $N$. morio and Noblonga, the latter did not feed on ripe fruit. The differences in the food of the larvae of Netocia species in the laboratory prevented us from comparing their life cycle durations. Studies on Scarabaeoidea show that temperature affects life cycle duration (Bourgin, 1946; Balachowsky, 1962; Kirk \& Kirk, 1990, Vernon \& Vannier, 2001), however there are no explicit descriptions of how the quality and quantity of food affect larval development.

ACKNOWLEDGEMENTS. Kate Burke checked an early English version. The research was supported in part by BOS 2000-0148 project.

\section{REFERENCES}

BÁguena L. 1967: Los Scarabaeoidea de la Fanna Íbero-Balear y Pirenaica. Instituto Español de Entomología, (CSIC), Madrid, $575 \mathrm{pp}$

BALACHOWSKY A.S. 1962: Entomologie Appliqué à l'agriculture. 1. Coléoptères. Masson et $\mathrm{C}^{\text {ie }}$ (ed.), Paris, $564 \mathrm{pp}$.

Baraud J. 1977: Coléoptères Scarabaeoidea de l'Europe occidentale. Belgique, France, Grand Bretagne, Italie, Péninsule Ibérique. Nouv. Rev. Entomol. 4: 1-352.

Baraud J. 1992: Coléoptères Scarabaeoidea d'Europe. Faune de France et Régions Limitrophes 78. Fédération française des Sociétés de Sciences Naturelles de Lyon, Lyon, 856 pp.

Bourgin P. 1946: Note préliminaire sur les effects de la température au cours du dévelopement de Cetonia aurata L. (Col.: Scarabaeidae). Bull. Soc. Entomol. France 1946: 35-37.

CARNE P.B. 1951: Preservation techniques for scarabaeid and other insect larvae. Proc. Linn. Soc. N. S. W. 76: 26-30.

Deloya C. \& Morón M.A. 1994: Coleópteros Lamelicornios del Distrito de Jojutla, Morelos, México (Melolonthidae, Scarabaeidae, Trogidae y Passalidae). Listados Faunísticos de México (V). Instituto de Biología, Universidad Nacional Autónoma de México, México, $49 \mathrm{pp}$.

Edmons W.D. \& HalfFter G. 1978: Taxonomic review of immature dung beetles of the subfamily Scarabaeinae (Coleoptera: Scarabaeidae). Syst. Entomol. 3: 307-331. 
Galante E. \& Cartagena M.C. 1999: Comparison of Mediterranean dung beetles (Coleoptera: Scarabaeoidea) in cattle and rabbit dung. Environ. Entomol. 28: 420-424.

Golovianko Z.S. 1936: Les Larves les Plus Communes des Coléoptères Lamellicornes de la Partie Européenne de l'U.R.S.S. Tableaux analytiques de la faune de l'U.R.S.S. 20: 1-65. [in Russian]

Hardy A.R. 1988: Studies in the Euphoriina of the Americas (Coleoptera: Scarabaeidae). I. Introduction and generic concepts. Coleopt. Bull. 42: 1-9.

Janssens A. 1960: Faune de Belgique. Insectes Coléoptères Lamellicornes. Institut Royal des Sciences Naturelles de Belgique, Bruxelles, $411 \mathrm{pp}$.

KirK A.A. \& KirK G. 1990: Effect of temperature on egg development in Copris hispanus L. and Bubas bison (L.) (Coleoptera: Scarabaeidae). J. Aust. Entomol. Soc. 29: 89-90.

Klaussnttzer B.D. \& Krell F.-T. 1997: 6. Überfamilie: Scarabaeoidea. In: Klausnitzer B. (ed.): Die Larven der Käfer Mitteleuropas. 3. Band. Polyphaga Teil 2. Gustav Fischer Verlag, Jena, pp. 11-89.

KoRsChefsKy R. 1940: Bestimmungstabelle der häufigsten deutschen Scarabaeidenlarven. Arb. Physiol. Angw. Entomol. Berlin-Dahlem 7: 41-52.

Krajč́K M. 1998: Cetoniidae of the World. Catalogue 1. (Coleoptera: Cetoniidae). Unpublished MS, Typos Studio Most, 96 pp.

KRIKKEN J. 1984: A new key to the suprageneric taxa in the beetle family Cetoniidae, with annotated lists of the known genera. Zoolog. Verhandel. 210: 3-75.

Medvedev S.I. 1952: Larvae of Scarabaeid Beetles of the Fauna of the USSR. Opredeliteli po faune SSSR 47, Akad. Nauk SSSR, Moskva, Leningrad, 344 pp. [in Russian]

Medvedev S.I. 1964: Fauna SSSR, Coleoptera. Vol. X, 5, Scarabaeidae Cetoniinae, Valginae. Izdatel'stvo Akademii Nauk SSSR, Moskva, Leningrad, 376 pp.

Micó E., SMith A.B.T \& Morón M.A. 2000: New larval descriptions for two species of Euphoria Burmeister (Coleoptera: Scarabaeidae: Cetoniinae: Cetoniini: Euphorina) with a key to the known larvae and a review of the larval biology. Ann. Entomol. Soc. Am. 93: 795-801.

Micó E., Verdứ J. R. \& Galante E. 2001: Larval morphology of some Anisopliini grain beetles with a key to their larvae (Coleoptera: Scarabaeoidea: Rutelidae: Anomalinae). Eur. J. Entomol. 98: 311-320.

Miksić R. 1987: Monographie der Cetoniinae der Paläarktischen und Orientalischen Region. Coleoptera: Lamellicornia. 4. Cetoniini II. Grafićki zavod Hrvatske, Zagreb, 608 pp.

Mrrytowycz R. \& Gambale S. 1969: The distribution of dung hills and the behaviour of free-living rabbits Oryctolagus cuniculus on them. Forma Functi 1: 333-349.

Paulian R. 1959: Coléoptères Scarabeides. Faune de France, $2^{\mathrm{a}}$ ed. Lechevalier, Paris, $298 \mathrm{pp}$.

RATCLIFFE B.C. 1976: Notes on the biology of Euphoriaspis hirtipes (Horn) and descriptions of the larva and pupa (Coleoptera: Scarabaeidae). Coleopt. Bull. 30: 217-226.

Ritcher P.O. 1966: White Grubs and their Allies. A study of North American Scarabaeoid Larvae. Oregon State University Press, Corvallis, 219 pp.

TAUZIN P. 1993: Precision sur la repartition de quelques espèces de Cetoniinae Paléarctiques. Troisième note: Les Netocia Costa, 1852. L'Entomologist 49: 145-172.

Tomlinson P.B. 1990: The Structural Biology of Palms. Clarendon Press, Oxford, $477 \mathrm{pp}$.

VAN EMDEN F.I. 1941: Larvae of British beetles. II. A key to the British Lamellicornia larvae. Entomol. Mont. Mag. 77: 117-192.

Verdú J.R., Galante E. \& Lumaret J.P. 1998: Description de la larve de Bolbelasmus bocchus (Erichson) et position systematique du genre (Coleoptera: Geotrupidae: Bolboceratinae). Ann. Soc. Entomol. Fr (N.S.) 34: 245-251.

Vernon P. \& VANNIER G. 2001: Freezing susceptibility and freezing tolerance in Palaearctic Cetoniidae (Coleoptera). Can. J. Zool. 79: 67-74.

Wheeler W.M. 1910: Ants, their Structure, Development, and Behavior. Columbia Univ. Press, New York, 663 pp.

Received December 30, 2001; revised July 15, 2002; accepted September 10, 2002 